\title{
Cairaella henrii gen. n., sp. n., a parasite of Norops trachyderma (Polychrotidae), and Ophiotaenia nicoleae sp. n. (Eucestoda: Proteocephalidea), a parasite of Thecadactylus rapicauda (Gekkonidae), in Ecuador
}

\author{
Sandrine C. Coquille ${ }^{1,2}$ and Alain de Chambrier ${ }^{1}$ \\ ${ }^{1}$ Muséum d'histoire naturelle, Département des Invertébrés, CP 6434, CH-1211 Genève 6, Switzerland; \\ ${ }^{2}$ Université de Genève, Faculté des Sciences, Département de Zoologie et Biologie Animale, 30, quai Ernest-Ansermet, \\ CH-1211 Genève 4, Switzerland
}

Key words: Eucestoda, Proteocephalidea, Cairaella henrii, Ophiotaenia nicoleae, new genus, new species, morphology, Squamata

\begin{abstract}
Cairaella henrii gen. n., sp. n. (Proteocephalidea: Proteocephalinae) is described from the intestine of Norops trachyderma (Cope) (Polychrotidae) from San Pablo de Kantesiya in Ecuador. The new genus differs from the 12 other known genera of the Proteocephalinae (and all other proteocephalidean genera) by the presence of a dense network of osmoregulatory canals situated in the cortex and by the morphology of the scolex which is flattened dorsoventrally, with elongated deeply embedded suckers possessing a well-developed circular musculature situated in the anterolateral region, and by eggs with a three-layered embryophore possessing small outgrowths on its external surface. Ophiotaenia nicoleae sp. $\mathrm{n}$. is described from the intestine of Thecadactylus rapicauda (Houttuyn) (Gekkonidae) from San Pablo de Kantesiya in Ecuador. This new species is characterised by the testes arranged in two fields, numbering 142-204, the cirrus-sac length representing $21-33 \%$ of proglottis width, the genital pore situated in the middle of the proglottis or slightly anteriorly, and the ovary width representing $68-88 \%$ of proglottis width. It differs from 20 of 27 Ophiotaenia species parasitic in New World reptiles by the presence of an apical organ and from the remaining species by one to several other morphological characters, such as the number of testes, diameter and shape of the scolex, position of ventral and dorsal osmoregulatory canals, or the presence of a vaginal sphincter. Both taxa represent the first record of proteocephalidean tapeworms in polychrotid and gekkonid lizards, respectively.
\end{abstract}

Tapeworms of the order Proteocephalidea Mola, 1928 are frequent and widely distributed parasites of freshwater fishes, amphibians and reptiles (Rego 1994). Between 1983 and 1989, the Department of Invertebrates of the Natural History Museum in Geneva, in collaboration with the Ecuadorian Museum of Natural History, conducted a survey of the parasite fauna in Ecuador, with a main focus on reptiles and amphibians. During these investigations, Jean-Marc Touzet collected cestodes from gekkonid and polychrotid lizards in San Pablo de Kantesiya, Río Aguarico, Ecuador. These tapeworms belong to a new genus and new species, respectively, and are described in the present paper.

\section{MATERIALS AND METHODS}

The worms were fixed immediately after dissection with hot 4\% neutral formaldehyde solution, stained with Mayer's hydrochloric carmine solution, dehydrated in an ethanol series, cleared with eugenol (clove oil) and mounted in Canada balsam. Pieces of the strobila were embedded in paraffin wax, cross-sectioned (thickness 12-15 $\mu \mathrm{m}$ ), stained with Weigert's haematoxylin and counterstained with $1 \%$ acidic eosin B (de Chambrier 2001). Scoleces for scanning electron microscopy (SEM) were processed as follows: worms were dehydrated in a graded ethanol series $(80,96$, twice $100 \%)$, then transferred to a graded amyl acetate series, critical point-dried in $\mathrm{CO}_{2}$, sputter coated with gold and examined with a Zeiss 940A electron microscope at the Natural History Museum, Geneva. Eggs were studied in distilled water. All measurements are given in micrometres $(\mu \mathrm{m})$ unless otherwise stated. Abbreviations used in descriptions are as follows: $\mathrm{x}$ - mean; $\mathrm{n}$ - number of measurements; CV - coefficient of variability; OV percent of the width of ovary versus the width of the proglottis; $\mathrm{PP}$ - position of genital pore (cirrus pore) as \% of proglottis length; PC - percent of the length of cirrus-sac versus the width of the proglottis. MHNG INVE - Natural History Museum of Geneva Invertebrate Collection; IPCAS - Institute of Parasitology, BC AS CR, České Budějovice, Czech Republic; BMNH - The Natural History Museum, London, UK.

\section{RESULTS}

\section{Cairaella gen. n.}

Proteocephalidae, Proteocephalinae. Strobila acraspedote, anapolytic. Testes, ovary, vitellaria, and uterus medullary. Scolex flattened dorsoventrally, with four deep elongated suckers possessing well-developed circular musculature situated in anterolateral region. Suckers deeply embedded, their base adjoining. Internal longitudinal musculature well developed. Dense network of osmoregulatory canals situated in cortex around internal 

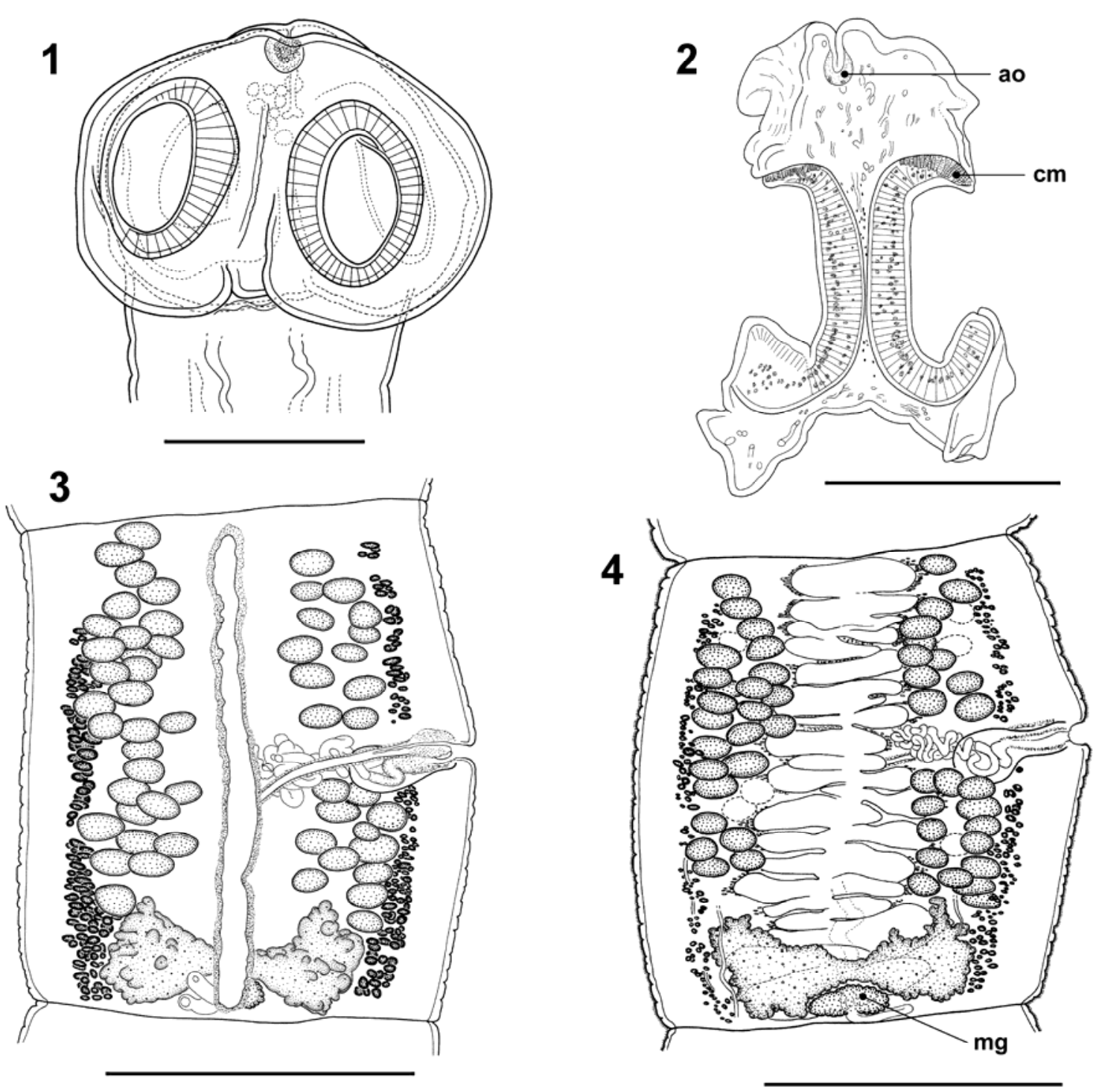

Figs. 1-4. Cairaella henrii sp. n., line drawings. Fig. 1. Holotype, scolex, ventral view (MHNG INVE 18889). Fig. 2. Paratype, scolex, sagittal section; note the presence of circular musculature in anterior margin of suckers (MHNG INVE 30504 ). Fig. 3. Holotype, mature proglottis, ventral view (MHNG INVE 18889). Fig. 4. Paratype, gravid proglottis, dorsal view (IPCAS C-499). Abbreviations: ao - apical organ; $\mathrm{cm}$ - circular musculature; mg - Mehlis' gland. Scale bars: Figs. 1, $2=250 \mu \mathrm{m} ;$ Figs. $3,4=$ $500 \mu \mathrm{m}$.

longitudinal musculature. Genital pores irregularly alternating, equatorial. Vitelline follicles forming two lateral bands, more numerous posteriorly. Testes medullary, in two separate lateral fields, in one or two layers. Ovary medullary, bilobed, folliculate. Uterus ventral, with lateral diverticula. Type 1 of uterine development (see de Chambrier et al. 2004). Eggs with threelayered embryophore and with small outgrowths on its external surface. Parasites of lizards (Polychrotidae). Type and the only species: Cairaella henrii sp. $\mathrm{n}$.

E t y m o $10 \mathrm{~g} \mathrm{y}$ : This genus is named in honour of Professor Janine N. Caira, University of Connecticut, USA, for her outstanding contribution to cestode systematics.
Differential diagnosis. Cairaella belongs to the Proteocephalinae because of medullary position of testes, ovary, vitellaria and uterus (Rego 1994). The new genus differs from the 12 other recognized genera of the Proteocephalinae (Proteocephalus Weinland, 1858; Crepidobothrium Monticelli, 1900; Ophiotaenia La Rue, 1911; Deblocktaenia Odening, 1963; Macrobothriotaenia Freze, 1965; Tejidotaenia Freze, 1965; Brayela Rego, 1984; Euzetiella de Chambrier, Rego et Vaucher, 1999; Pseudocrepidobothrium Rego et Ivanov, 2001; Thaumasioscolex Cañeda-Guzmán, de Chambrier et Scholz, 2001; Glanitaenia de Chambrier, Zehnder, Vaucher et Mariaux, 2004; and Scholzia de Chambrier, 

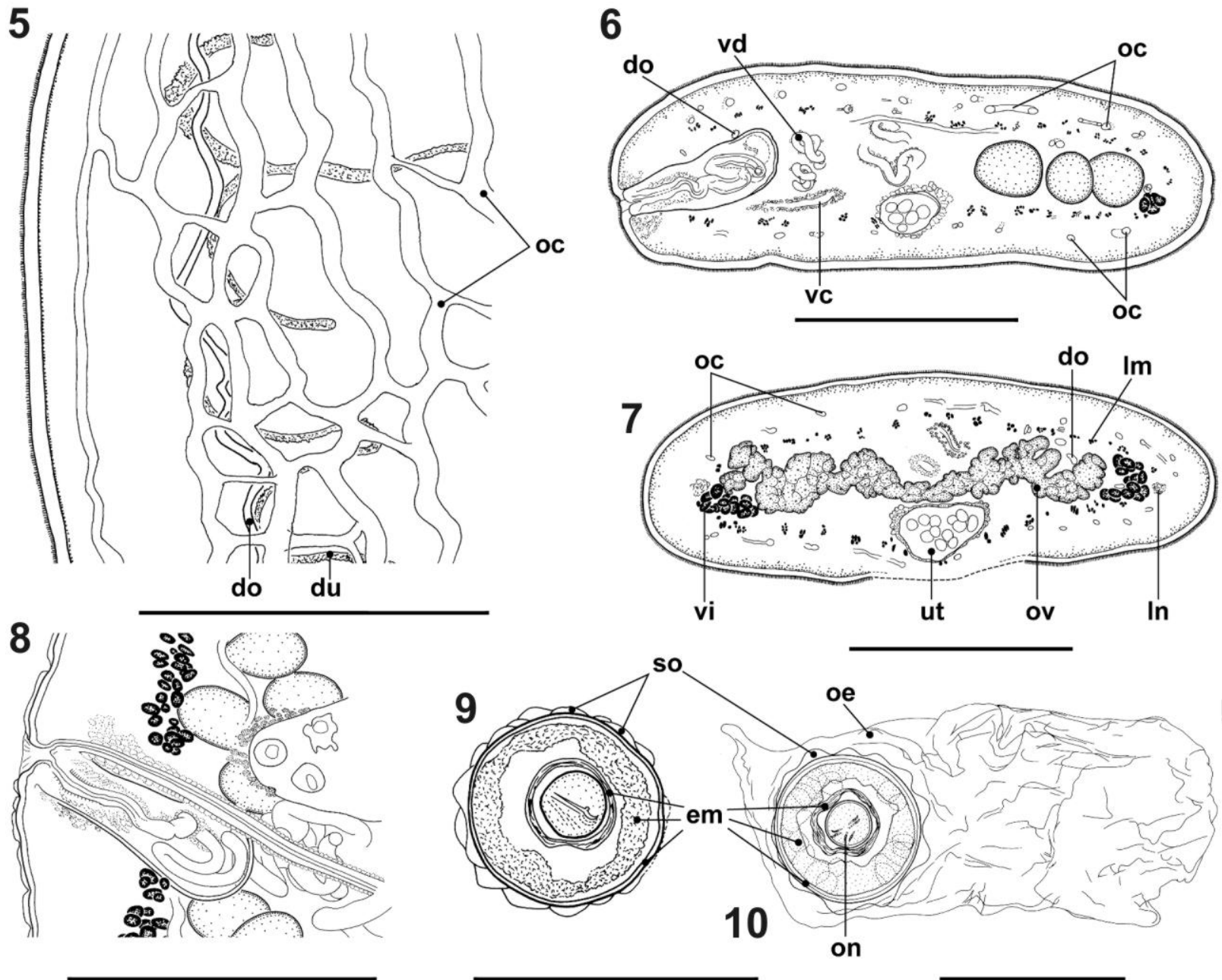

Figs. 5-10. Cairaella henrii sp. n., line drawings. Fig. 5. Holotype, posterolateral part of gravid proglottis showing the network of cortical osmoregulatory canals, dorsal view (MHNG INVE 18889). Figs. 6, 7. Paratype, cross-sections at level of cirrus-sac and ovary, respectively (MHNG INVE 60715). Fig. 8. Holotype, vagina and cirrus-sac region, ventral view (MHNG INVE 18889). Figs. 9, 10. Eggs drawn in distilled water, showing the three-layered embryophore and small outgrowths (MHNG INVE 23861). Abbreviations: do - dorsal osmoregulatory canal; du - uterine diverticles; em - embryophore; $1 \mathrm{~m}$ - internal longitudinal musculature; ln - longitudinal nerve; oc - osmoregulatory canals; oe - outer envelope; on - oncosphere; ov - ovary; ut - uterus; so - small outgrowths; vc - vaginal canal; vd - vas deferens; vi - vitelline follicles. Scale bars: Figs. $5-8=250 \mu \mathrm{m} ;$ Figs. $9,10=$ $50 \mu \mathrm{m}$.

Rego et Gil de Pertierra, 2005) by the presence of a dense network of cortical osmoregulatory canals, which is unique in proteocephalidean cestodes (Freze 1965, Schmidt 1986, Rego 1994, de Chambrier and Vaucher 1999, Rego et al. 1999, Rego and Ivanov 2001, de Chambrier et al. 2004, 2005). Furthermore, Cairaella differs from all 12 genera by the morphology of the eggs, which have a three-layered embryophore. It also differs from all but one of these genera (Thaumasioscolex from an opossum from Mexico - Cañeda-Guzmán et al. 2001) by the presence of small outgrowths covering the external surface of the embryophore. In addition, Cairaella is characterized by the morphology of its scolex, which is flattened dorsoventrally and possesses deeply embedded elongated suckers with their base ad- joining (Fig. 2). The suckers possess well-developed circular musculature situated in the anterolateral region, which is not common characteristic among proteocephalidean cestodes, being present only in some species as, for example, in Brooksiella praeputialis (Rego, Santos et Silva, 1974) or in Proteocephalus jarara (Fuhrmann, 1927) (see de Chambrier et al. 1991, 2004b).

Cairaella henrii sp. n.

Figs. 1-14

Description (based on seven specimens): Proteocephalidae, Proteocephalinae. Cestodes 17-26 mm long, up to 765 wide. Strobila acraspedote, anapolytic, con sisting of 36-39 $(n=3)$ proglottides: 25-28 immature (up to appearance of spermatozoa in vas deferens), 3 mature (up to appearance of eggs in uterus), 7-11 pre- 

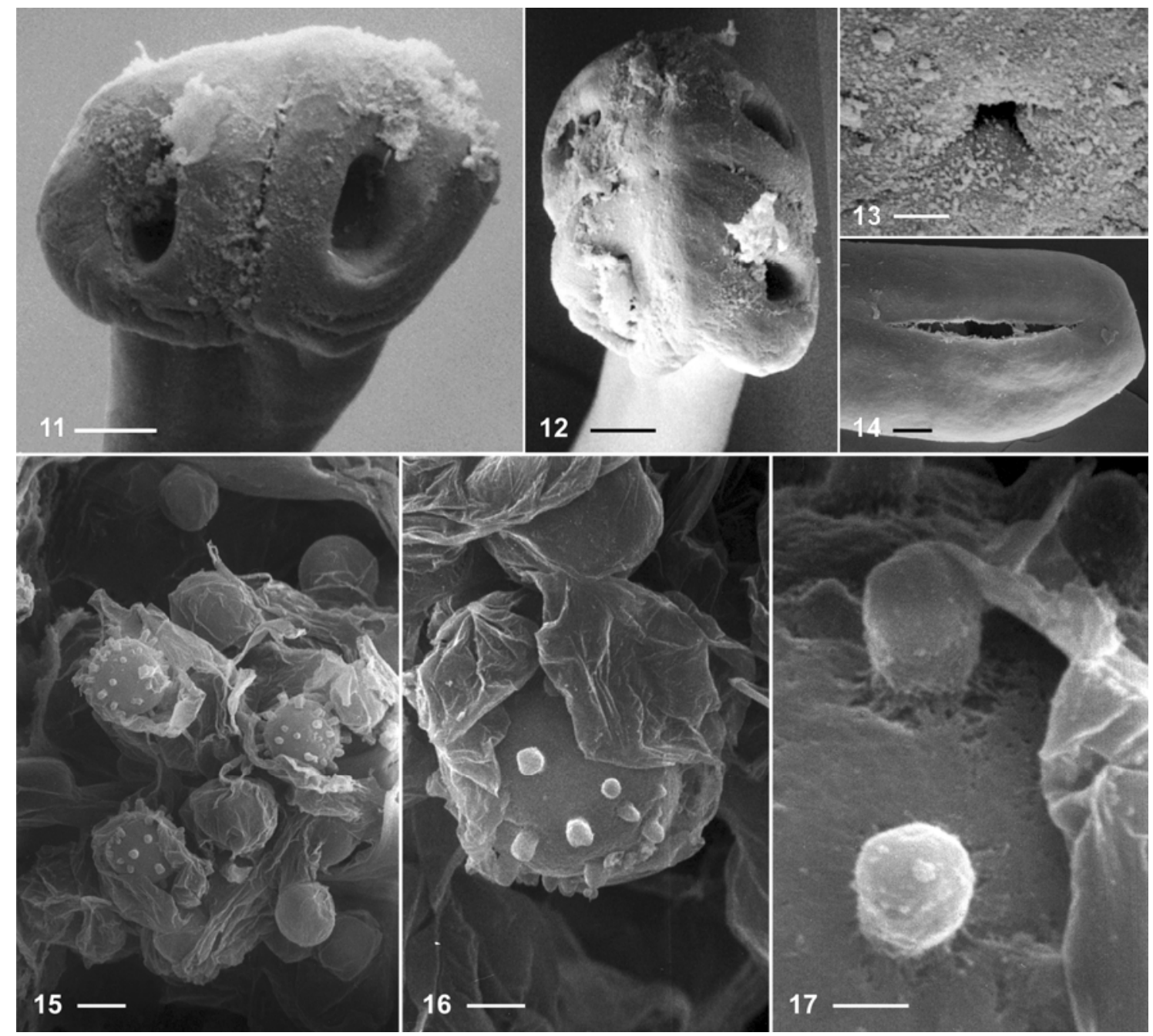

Figs. 11-14. Cairaella henrii sp. n., scanning electron micrographs (MHNG INVE 60716). Fig. 11. Scolex, anterolateral view. Fig. 12. Scolex, apical view. Fig. 13. Gravid proglottis showing the slit-like ventral uterine aperture. Fig. 14. Scolex, apical view, detail of the apical aperture. Figs. 15-17. Vaucheriella bicheti de Chambrier, 1987, parasitic in Tropidophis cf. taczanowskyi from Ecuador; scanning electron micrographs (MHNG INVE 12408). Fig. 15. Eggs within the uterus, showing the outer envelope and the outgrowths on the external surface of the embryophore. Figs. 16, 17. Details of the external outgrowths of the embryophore. Scale bars: Figs. 11, 12, $14=50 \mu \mathrm{m}$; Fig. $13=5 \mu \mathrm{m}$; Fig. $15=10 \mu \mathrm{m}$; Fig. $16=4 \mu \mathrm{m}$; Fig. $17=1 \mu \mathrm{m}$.

gravid (up to appearance of hooks in oncospheres) and gravid proglottides.

Immature and mature proglottides wider than long to longer than wide (length:width ratio 0.11-1.69), pregravid and gravid proglottides longer than wide (length:width ratio 1.03-3.34). Scolex dorsoventrally flattened (Fig. 2), 85-395 ( $\mathrm{x}=390, \mathrm{n}=3)$ long and $535-650(\mathrm{x}=585, \mathrm{n}=3)$ wide, much wider than neck (Figs. 11, 12) with small ovoid apical organ, 54-67 $(\mathrm{x}=$ $60, n=3)$ long and $42(n=3)$ wide (Figs. 1, 2, 13). Suckers uniloculate, ovoid, elongated, deeply embedded, 230-260 $(\mathrm{x}=245, \mathrm{n}=12)$ long and $160-190(\mathrm{x}=$ $175, \mathrm{n}=12)$ wide, their base adjoining in cross-section. Sucker diameter representing $26-33 \%$ of scolex diameter (Fig. 1). Suckers with well-developed circular mus- culature situated in anterolateral region (Fig. 2). Proliferation zone $255-330(x=290, n=3)$ wide.

Internal longitudinal musculature developed, represented by bundles of separated muscular fibres (Figs. 6, 7) forming anastomoses. Osmoregulatory canals forming dense network, in cortical parenchyma (Figs. 5-7), with about 20-27 longitudinal canals in the dorsal and ventral cortex.

Testes medullary, forming three groups (poral field separated to preporal and postporal groups), in one or two layers, sometimes slightly overlapping cirrus-sac, vagina, vas deferens and vitelline follicles (Figs. 3, 4), numbering $45-57(\mathrm{x}=52, \mathrm{n}=9, \mathrm{CV}=7 \%)$; aporal testes $24-31$ in number $(\mathrm{x}=27) ; 11-17$ preporal testes $(\mathrm{x}=$ 14); 7-12 postporal testes $(\mathrm{x}=10)$. Testes spherical to 
oval, 45-65 $(\mathrm{x}=55, \mathrm{n}=15)$ long and $30-50(\mathrm{x}=38, \mathrm{n}$ $=15$ ) wide, reaching almost to anterior margin of proglottides, but not to posterior one (Fig. 3); present also in gravid proglottides (Fig. 4).

Cirrus-sac pyriform, thick-walled, with distal part tapered, $170-195(x=182, n=9)$ long and $60-75(x=65$, $\mathrm{n}=9$ ) wide (Figs. 6, 8); PC 23-28\% ( $\mathrm{x}=26 \%, \mathrm{n}=9$, $\mathrm{CV}=7 \%$ ). Cirrus representing up to $50 \%$ of cirrus-sac length. Vas deferens coiled, situated between proximal part of cirrus-sac and midline of proglottides, often crossing it.

Genital atrium present, pores alternating irregularly, usually equatorial or slightly pre-equatorial; $\mathrm{PP}=44$ $52 \%(\mathrm{x}=48 \%, \mathrm{n}=9, \mathrm{CV}=5 \%)$ (Figs. 3, 4). Genital ducts passing between osmoregulatory canals.

Ovary medullary, bilobate, follicular in pregravid proglottides (Figs. 4, 7), with dorsal outgrowths rarely reaching dorsal cortex (Fig. 7), 360-435 ( $\mathrm{x}=410, \mathrm{n}=$ 9) wide, $\mathrm{OV}=56-64 \%(\mathrm{x}=60 \% ; \mathrm{n}=9 ; \mathrm{CV}=4 \%)$. Mehlis' glands $110-145(\mathrm{x}=135, \mathrm{n}=9)$ in diameter, representing 15-20\% of proglottis width (Fig. 4).

Vitelline follicles medullary, arranged in two lateral fields near margins of proglottides, more numerous posteriorly, situated near ventral side in cross sections (Figs. 6, 7), occupying 76-93\% $(\mathrm{x}=88 \%, \mathrm{n}=9)$ of proglottis length, interrupted at level of cirrus sac. Ventral follicles sometimes overlapping testes (Fig. 4). Vitelline follicles degenerate in gravid proglottides before degeneration of testes.

Vaginal canal forming small seminal receptacle anterodorsal to ovarian isthmus, vaginal canal curved before reaching seminal receptacle. Terminal part of vaginal canal (pars copulatrix vaginae) surrounded by chromophilic cells. Vagina anterior $92 \%$ or posterior $8 \%$ (n $=62$ ), always ventral to cirrus-sac.

Primordium of uterine stem medullary, present in immature proglottides. Formation of uterus of type 1 (see de Chambrier et al. 2004): in immature proglottides, uterine stem straight, occupying entire length of proglottis, formed by longitudinal thick band of chromophilic cells along midline of proglottides. Lumen of uterus appearing in first mature proglottides (Fig. 3); diverticula (lateral branches) formed before first eggs appear in uterine stem. In pregravid proglottides, eggs completely filling uterine stem and thick-walled diverticula. In gravid proglottides, diverticula occupying up to $73 \%(\mathrm{n}=13)$ of proglottis width; $13-17(\mathrm{x}=15, \mathrm{n}=$ 12) lateral branches on each side. Some terminal gravid proglottides inflated with eggs, elongated and almost tubular, with visible longitudinal ventral uterine pores (Fig. 14).

Eggs round, outer envelope $70-105(x=88, n=3)$ in diameter (Fig. 10). Embryophore spherical, with thick supplementary spherical layer between outer envelope and oncosphere, representing three-layered embryophore: first layer $17-19(\mathrm{n}=6)$ in diameter, second layer 32-34 $(n=6)$ in diameter; third layer 35-37 $(n=$ 6) in diameter; oncosphere spherical to oval, 11-12 in diameter $(n=6)$, with three pairs of hooks, 7-8 long
(Figs. 9, 10). Eggs increase in size during intrauterine development. External surface of embryophore bearing small flattened outgrowths (Figs. 9, 10).

$\mathrm{T}$ y p e h o s t : Norops trachyderma (Cope, 1876) (Squamata, Polychrotidae) (common name: common forest anole).

T y p e 1 o c a 1 i t y : San Pablo de Kantesiya, Río Aguarico, Ecuador $\left(0^{\circ} 15^{\prime}\right.$ 'S, $\left.76^{\circ} 26^{\prime} \mathrm{W}\right), 13.02 .1988$.

$\mathrm{S}$ i t e : First quarter of intestine, immediately after stomach.

Prevale n c e: $13 \%$ (3 of 23 ).

T y p e m a t e r i a 1: Holotype MHNG INVE 18889 (field number Ec 4222) (1 slide); 3 paratypes MHNG INVE 60713 (1 slide), 60715 (6 slides, 1 whole mounted and 5 cross-sections); IPCAS C-499 (1 slide); BMNH 2008.5. 20.1 (1 cross-section from the paratype 60715) (all field number Ec 4222); 1 paratype MHNG INVE 30504, San Pablo de Kantesiya, Río Aguarico, Ecuador, 22.02.1988 (8 slides, 1 whole mounted and 7 cross-sections) (field number Ec 4375).

$\mathrm{V}$ o u c h e r m a t e r i a $1: 1$ specimen used for SEM, MHNG INVE 60716 (field number Ec 4222); 4 specimens in vials, MHNG INVE 60717 (field number Ec 4222); 1 specimen, MHNG INVE 23861, San Pablo de Kantesiya, Río Aguarico, Ecuador, 9.02.1988 (5 slides, 1 whole mounted and 4 cross-sections) (field number Ec 4111).

E t y m o 1 o g y : The species has been named in honour of Henri Coquille (Geneva), first author's father.

Remarks. The presence of a three-layered embryophore similar to that described above has already been observed in Ophiotaenia alessandrae Marsella et de Chambrier, 2008 by Marsella and de Chambrier (2008). Structures similar to the numerous outgrowths on the external surface of the embryophore of Cairaella henrii are observed in some proteocephalidean cestodes parasitic in terrestrial vertebrates, such as Vaucheriella bicheti de Chambrier, 1987 from a tropidophid snake (Figs. 15-17), Nomimoscolex touzeti de Chambrier et Vaucher, 1992 from a Neotropical frog, Proteocephalus azevedoi de Chambrier, Vaucher et Renaud, 1992 from a Neotropical venomous snake, or Thaumasioscolex didelphidis Cañeda-Guzmán, de Chambrier et Scholz, 2001 from a Mexican marsupial (de Chambrier 1987, de Chambrier and Vaucher 1992, de Chambrier et al. 1992, Cañeda-Guzmán et al. 2001).

The presence of a network of osmoregulatory canals in the cortex is very rarely observed in the Cestoda. Osmoregulatory canals in cestodes usually consist of a pair of ventral and a pair of dorsal canals situated in the medullary parenchyma (Fuhrmann 1933, Wardle and McLeod 1952). The number of canals increased in a few groups, as in some cyclophyllideans (e.g. six canals in Fimbriaria Froelich, 1802, 11 in Fimbriaroides Fuhrmann, 1932 and up to 20 in Raillietina vigintivasus (Skryabin, 1914) - Joyeux and Baer 1961), but remain all situated in the medullary parenchyma. In some cases, longitudinal canals are interconnected by numerous transverse canals (Ligula Bloch, 1782, Schistocephalus Creplin, 1829, Eubothrium Nybelin, 1920). In Diphyllobothrium Cobbold, 1858, however, the network expands 
from the medulla to the cortex (Joyeux and Baer 1961). Markowski (1952a, b) observed a cortical network of osmoregulatory canals, similar to those observed in Cairaella henrii, in several species of Diphyllobothrium, e.g., D. hians (Diesing, 1850) (fig. 30 in Markowski 1952a), D. quadratum (Linstow, 1892), D. lashleyi (Leiper et Atkinson, 1914), and also in Baylisiella tecta (Linstow, 1892).

In the Proteocephalidea, the wall of dorsal canals is thicker than that of the ventral ones. In C. henrii (Figs. 5-7) and in Diphyllobothrium hians (fig. 30 - Markowski 1952a), the canals situated in the medulla are thicker than the ones in the cortex. This may indicate that cortical canals of these species are homologous to the ventral ones which were originally located in the medulla.

Within the Proteocephalidea, the development of a network of osmoregulatory canals within the cortex has only been observed in Nomimoscolex touzeti de Chambrier et Vaucher, 1992, a parasite of Ceratophrys cornuta (L.) in Ecuador, which possesses five main longitudinal canals on each side of proglottides connected by numerous transverse canals (see figs. 4-6, 8 in de Chambrier and Vaucher 1992) in the ventral cortex. In C. henrii, the network is composed of 20-27 main longitudinal canals, connected by numerous transverse canals, situated all around and exterior to the longitudinal internal musculature (Figs. 6,7). The presence of such a network occupying the whole cortical parenchyma represents a unique feature within the Proteocephalidea and is also very rare within the Cestoda.

\section{Ophiotaenia nicoleae sp. $\mathrm{n}$.}

Figs. 18-24

Description (based on 2 specimens): Proteocephalidae, Proteocephalinae. Cestodes 230-515 mm long, up to $2.2 \mathrm{~mm}$ wide. Strobila acraspedote, anapolytic, consisting of 322-381 $(n=2)$ proglottides: 248-302 immature (up to appearance of spermatozoa in vas deferens), 7-32 mature (up to appearance of eggs in uterus), 42-72 pregravid (up to appearance of hooks in oncospheres) and gravid proglottides.

Immature and mature proglottides wider than long to longer than wide (length:width ratio 0.19-2.4), pregravid and gravid proglottides longer than wide (length: width ratio $1.8-3.25$ ). Scolex $325-340$ in diameter and 265-275 long, with apical organ 22-38 long and 22-26 wide. Proliferation zone narrower than scolex, 245-270 wide. Suckers anterolateral, uniloculate, spherical to ovoid, $128-150(\mathrm{x}=137, \mathrm{n}=8)$ long and 106-128 $(\mathrm{x}=$
$117, \mathrm{n}=8$ ) wide. Sucker diameter representing 33-42\% of scolex diameter (Fig. 18).

Internal longitudinal musculature well-developed, composed of a layer of fine bundles of separated muscular fibres forming anastomoses (Figs. 21, 22). Osmoregulatory canals situated at $20-25 \%$ of proglottis width from lateral margin, separating longitudinally each testis fields in two bands (Figs. 19, 20, 23). Ventral canals much wider than dorsal ones. Dorsal canals situated more medially than ventral one.

Testes medullary, forming two longitudinal lateral fields in one (rarely two) layer, not overlapping cirrussac, vagina and vas deferens (Figs. 20, 23), numbering $142-204(\mathrm{x}=176, \mathrm{n}=17, \mathrm{CV}=12 \%)$; aporal testes $68-$ 104 in number $(\mathrm{x}=89)$; preporal testes $37-61(\mathrm{x}=46)$; postporal testes $29-52(\mathrm{x}=41)$. Testes spherical to oval, 45-83 ( $\mathrm{x}=63, \mathrm{n}=20)$ long, $35-74(\mathrm{x}=54, \mathrm{n}=20)$ wide, barely reaching vitelline follicles laterally, not present near anterior and posterior margin (Figs. 19, 20), still present in gravid proglottides.

Cirrus-sac elongated, thick-walled, 325-565 (x = $430, \mathrm{n}=17, \mathrm{CV}=16 \%)$ long and $100-185(\mathrm{x}=145, \mathrm{n}=$ $17, \mathrm{CV}=17 \%$ ) wide (Fig. 23$) ;$ PC $21-33 \%(\mathrm{x}=26 \%, \mathrm{n}$ $=17, \mathrm{CV}=13 \%)$. Cirrus length representing up to $70 \%$ of cirrus-sac length. Posterior part of cirrus very long and coiled. Vas deferens strongly coiled, situated between proximal part of cirrus sac and midline of proglottides, wider in its terminal part (Figs. 20, 23).

Genital atrium deep, genital pores alternating irregularly, usually situated in middle of proglottis length (equatorial) or slightly anteriorly; $\mathrm{PP}=34-53 \%(\mathrm{x}=$ $47 \%, \mathrm{n}=17, \mathrm{CV}=9 \%$ ). Genital ducts passing between osmoregulatory canals (Fig. 20).

Ovary medullary, bilobed, follicular, $850-1,605$ ( $\mathrm{x}=$ $1,190, \mathrm{n}=17)$ wide, $\mathrm{OV}=68-88 \%(\mathrm{x}=75 \% ; \mathrm{n}=17$; $\mathrm{CV}=6 \%)($ Figs. 20, 22). Mehlis' glands 95-130 (x $=$ $110, \mathrm{n}=17, \mathrm{CV}=9 \%$ ) in diameter, representing $5-10 \%$ of proglottis width (Figs. 19, 20, 22).

Vitelline follicles medullary, arranged in two lateral ventral fields near margins of proglottides, slightly more numerous posteriorly, occupying 78-96\% $(\mathrm{x}=91 \%, \mathrm{n}=$ $17, \mathrm{CV}=5 \%$ ) of proglottis length, interrupted at level of cirrus sac and vagina (Figs. 19-23). Vagina anterior $72 \%$ or posterior $28 \%(\mathrm{n}=237)$ to cirrus-sac. Terminal part of vaginal canal (pars copulatrix vaginae) surrounded by ring-shaped muscular sphincter (Fig. 23). Vaginal canal slightly curved just before reaching seminal receptacle. Seminal receptacle situated dorsal to ovarian isthmus.

Figs. 18-24. Ophiotaenia nicoleae sp. n., line drawings. Fig. 18. Scolex, dorsoventral view. Fig. 19. Holotype, mature proglottis in dorsal view (MHNG INVE 18676). Fig. 20. Paratype, gravid proglottis in ventral view (MHNG INVE 18678). Note that the cirrus is penetrating the vagina. Fig. 21. Paratype, cross-section at the level of anterior part of the pregravid proglottis (MHNG INVE 18678). Fig. 22. Paratype, cross-section at level of the ovary (MHNG INVE 18678). Fig. 23. Holotype, vagina and cirrussac region, dorsal view (MHNG INVE 18676). Fig. 24. Paratype, eggs drawn in distilled water (MHNG INVE 18678). Abbreviations: ao - apical organ; do - dorsal osmoregulatory canal; em - bilayered embryophore; $1 \mathrm{~m}$ - internal longitudinal musculature; mg - Mehlis' gland; oe - outer envelope; on - oncosphere; ov - ovary; ps - discrete polar swelling; te - testes; vi - vitelline follicles; vo - ventral osmoregulatory canal; vs - vaginal sphincter. Scale bars: Figs. 18, 22, $23=250 \mu \mathrm{m}$; Fig. $19=500 \mu \mathrm{m}$; Figs. $20,21=1,000 \mathrm{~mm}$; Fig. $24=50 \mu \mathrm{m}$ 

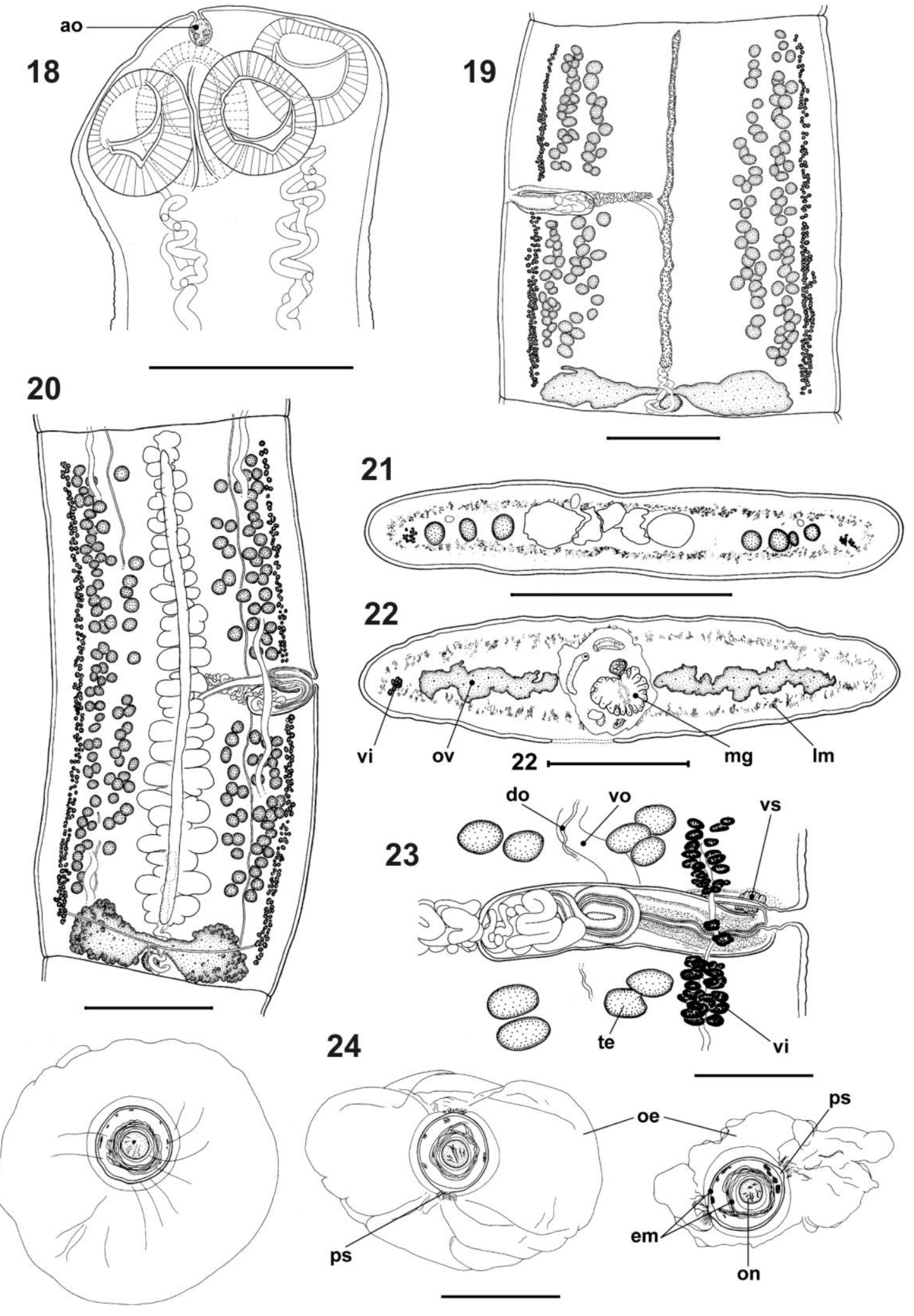
Table 1. Proteocephalidean cestodes parasitic in reptilian hosts in the New World (in bold, the species possessing an apical organ).

\begin{tabular}{|c|c|c|}
\hline Parasite species & Host species & Country \\
\hline Ophiotaenia agkistrodontis (Harwood, 1933) & Agkistrodon piscivorus (Lacépède) & USA \\
\hline Ophiotaenia arandasi (Santos et Tayt-Son Rolas, 1973) & Liophis miliaris (Linnaeus) & Brazil \\
\hline Ophiotaenia azevedoi (de Chambrier et Vaucher, 1992) & Bothrops jararaca (Wied) & Brazil \\
\hline Ophiotaenia barbouri Vigueras, 1934 & Tretanorhinus variabilis Dum., Bib. et Dum. & Cuba \\
\hline Ophiotaenia calmettei (Barrois, 1898) & Bothrops lanceolatus (Lacépède) & Martinique \\
\hline Ophiotaenia catzeflisi (de Chambrier et Vaucher, 1992) & Bothrops jararaca (Wied) & Brazil \\
\hline Ophiotaenia crotali Lopez-Neyra et Díaz-Ungría, 1958 & Crotalus durissus terrificus (Laurenti) & Venezuela \\
\hline Ophiotaenia elongata Fuhrmann, 1927 & "small snake" & Brazil \\
\hline Ophiotaenia euzeti (de Chambrier et Vaucher, 1992) & Bothrops jararaca (Wied) & Brazil \\
\hline Ophiotaenia faranciae MacCallum, 1921 & Farancia abacura Holbrook & USA \\
\hline Ophiotaenia flava Rudin, 1917 & Coluber sp. & Brazil \\
\hline Ophiotaenia gilberti Ammann et de Chambrier, 2008 & Thamnodynastes pallidus (Linnaeus) & Paraguay \\
\hline Ophiotaenia grandis La Rue, 1911 & Agkistrodon piscivorus (Lacépède) & USA \\
\hline Ophiotaenia habanensis Freze et Ryšavý, 1976 & Tropidophis pardalis (Gundlach) & Cuba \\
\hline Ophiotaenia hyalina Rudin, 1917 & Coluber sp. (presumably Liophis) & Brazil \\
\hline Ophiotaenia jarara Fuhrmann, 1927 & Bothrops jararaca (Wied) & Brazil \\
\hline Ophiotaenia joanae (de Chambrier et Paulino, 1997) & Xenodon neuwiedi Günther & Brazil \\
\hline Ophiotaenia lactea (Leidy, 1855) & Natrix sipedon (Linnaeus) & USA \\
\hline Ophiotaenia macrobothria Rudin, 1917 & Elaps corallinus Merrem & Brazil \\
\hline Ophiotaenia marenzelleri (Barrois, 1898) & Agkistrodon piscivorus (Lacépède) & USA \\
\hline Ophiotaenia micruricola (Shoop et Corkum, 1982) & Micrurus diastema (Dum., Bib. et Dum.) & Mexico \\
\hline Ophiotaenia nattereri (Parona, 1901) & Coluber sp. & Brazil \\
\hline Ophiotaenia paraguayensis Rudin, 1917 & Hydrodynastes gigas (Dum., Bib. et Dum.) & Paraguay \\
\hline Ophiotaenia perspicua La Rue, 1911 & Natrix rhombifer (Hallowell) & USA \\
\hline Ophiotaenia racemosa (Rudolphi, 1819) & Coluber sp. & Brazil \\
\hline Ophiotaenia sanbernardinensis Rudin, 1917 & Helicops leopardinus (Schlegel) & Paraguay \\
\hline Ophiotaenia variabilis (Brooks, 1978) & Natrix cyclopion (Dum., Bib. et Dum.) & USA \\
\hline
\end{tabular}

Table 2. Proteocephalidean species parasitic in Sauria (Lacertilia) in the World.

\begin{tabular}{|c|c|c|}
\hline Parasite species & Host species & Region \\
\hline \multicolumn{3}{|l|}{ Acanthotaenia von Linstow, 1903} \\
\hline A. biroi (Ratz, 1900) & Varanus sp. & New Guinea \\
\hline A. daileyi Schmidt et Kuntz, 1974 & Varanus salvator (Laurenti) & Philippines \\
\hline A. gracilis (Beddard, 1913) & Varanus varius (White) & Australia \\
\hline A. overstreeti Brooks et Schmidt, 1978 & Cyclura stejnegeri (Barbour et Noble) & Porto Rico \\
\hline A. shipleyi Linstow, 1903 & Varanus salvator (Laurenti) & South-East Asia \\
\hline \multicolumn{3}{|l|}{ Kapsulotaenia Freze, 1965} \\
\hline K. frezei Schmidt et Kuntz, 1974 & Varanus salvator (Laurenti) & Philippines \\
\hline K. saccifera (Ratz, 1900) & Varanus sp. & New Guinea \\
\hline K. sangroundi (Carter, 1943) & Varanus komodoensis Ouwens & Indonesia \\
\hline K. tidswelli (Johnston, 1909) & Varanus varius (White) & Australia \\
\hline K. varia (Beddard, 1913) & Varanus varius (White) & Australia \\
\hline \multicolumn{3}{|l|}{ Ophiotaenia La Rue, 1911} \\
\hline O. striata (Johnston, 1914) & Lialis burtonii Gray & Australia \\
\hline O. amphiboluri (Nybelin, 1917) & Pogona barbata (Cuvier) & Australia \\
\hline O. greeri (Bursey, Goldberg et Kraus, 2006) & Sphenomorphus aignanus (Boulenger) & Papua New Guinea \\
\hline \multicolumn{3}{|l|}{ Rostellotaenia Freze, 1963} \\
\hline R. beddardi (Woodland, 1925) & Varanus bengalensis (Daudin) & India \\
\hline R. nilotica (Beddard, 1913) & Varanus niloticus Linnaeus & North Africa \\
\hline R. woodlandi (Moghe, 1926) & Varanus bengalensis (Daudin) & India \\
\hline \multicolumn{3}{|l|}{ Tejidotaenia Freze, 1965} \\
\hline T. appendiculata (Baylis, 1947) & Tupinambis nigropunctatus (Spix) & Dutch Guyana \\
\hline
\end{tabular}

Primordium of uterine stem medullary, present in immature proglottides. Formation of uterus of type 1 (see de Chambrier et al. 2004): in immature proglottides, uterine stem straight, occupying almost entire length of proglottis, formed by longitudinal thick column of chromophilic cells along midline of proglottides
(Fig. 19). Lumen of uterus appearing in first mature proglottides. Diverticula (lateral branches) formed before first eggs appear in uterine stem. In pregravid proglottides, eggs completely filling uterine stem and thick-walled diverticula. In gravid proglottides, diverticula occupying up to $66 \%$ of proglottis width; $13-27$ 
$(\mathrm{x}=19, \mathrm{n}=30, \mathrm{CV}=15 \%)$ lateral branches on each side (Fig. 20). Longitudinal slit-like ventral uterine opening observable in some terminal proglottides.

Eggs with hyaline outer envelopes, 105-145 in diameter (Fig. 24). Embryophore spherical, bilayered. First layer 32-36 in diameter, with two discrete polar swellings; second layer 18-24 in diameter; oncosphere spherical to oval, 11-13 in diameter, with three pairs of hooks, 6-7 long (Fig. 24).

$\mathrm{T}$ y $\mathrm{p}$ e h o s t: Thecadactylus rapicauda (Houttuyn, 1782) (Squamata, Gekkonidae); common name: turnip-tailed gecko.

T y p e 1 o c a 1 i t y : San Pablo de Kantesiya, Río Aguarico, Ecuador $\left(0^{\circ} 15^{\prime} \mathrm{S}, 76^{\circ} 26^{\prime} \mathrm{W}\right)$.

$\mathrm{S}$ ite of infection: Intestine.

Prevale n c e: $22 \%$ (2 of 9 ).

T y p e m a t e r i a 1: Holotype MHNG INVE 18676, San Pablo de Kantesiya, Río Aguarico, Ecuador, 23.2.1985, 1 entire specimen in 5 whole mounts (field number Ec 244). Paratypes MHNG INVE 18678, San Pablo de Kantesiya, Río Aguarico, Ecuador, 25.9.1986, 4 whole mounts, 12 cross-sections and BMNH 2008.5.20.2, 1 cross-section (both field number Ec 2199).

E t y m o lo g y: The species has been named in honour of Nicole Coquille (Geneva), first author's mother.

Differential diagnosis. The present species is placed in Ophiotaenia La Rue, 1911 (subfamily Proteocephalinae) because of the medullary position of the vitellaria, unarmed scolex, shape of uniloculate suckers, and the testes arranged in two fields (Freze 1965, Schmidt 1986). Ninety-two species of Ophiotaenia parasitizing reptiles and amphibians are currently recognized as valid (Freze 1965, Schmidt 1986, Ammann and de Chambrier 2008, Marsella and de Chambrier 2008). In the New World, 27 Ophiotaenia species are known to parasitize snakes, but none has been found in lizards (Shoop and Corkum 1982, Schmidt 1986, de Chambrier 1990, de Chambrier et al. 1991, 1992, de Chambrier and Paulino 1997, Ammann and de Chambrier 2008) (Table 1). Ophiotaenia nicoleae differs from 20 of them in the presence of an apical organ (Table 1). Of the seven remaining Ophiotaenia taxa from snakes which possess an apical organ (Table 1, in bold), $O$. faranciae (number of testes $=380-420)$, O. marenzelleri (230-240) and $O$. gilberti (57-91) differ from Ophiotaenia nicoleae by the number of testes (142-204); O. jarara (diameter of scolex $=1,220)$ and $O$. catzeflisi $(990-1,220)$ differ by the diameter of the scolex (325-340 in O. nicoleae), and by the position of ventral and dorsal osmoregulatory canals, situated between testes and vitelline follicles in $O$. grandis, O. jarara and O. catzeflisi, versus overlapping and separating longitudinally the testicular fields in $O$. nicoleae. Ophiotaenia joanae differs from $O$. nicoleae by the presence of a swollen elongated posterior part of the scolex. Furthermore, neither O. faranciae, nor $O$. grandis, nor $O$. marenzelleri possesses a vaginal sphincter.
Remarks. Ophiotaenia nicoleae is the first proteocephalidean cestode found in a gekkonid lizard. It should be noted that its strobila is very long (reaching up to $515 \mathrm{~mm}$ ) in comparison with the total length of the host (max. $220 \mathrm{~mm}$ ) (Rösler 1995).

The position of the osmoregulatory canals, which overlap and separate longitudinally the testicular fields, is not common in Ophiotaenia. Judging from the original descriptions and drawings, only 3 out of 27 Ophiotaenia species parasitic in snakes of the New World, namely O. azevedoi, O. euzeti, and O. gilberti, harbour this character. Since this character is constant, it represents a good discriminative feature, as already pointed out for Nomimoscolex Woodland, 1934 by de Chambrier et al. (2006).

The eggs of $O$. nicoleae possess discrete polar swellings on the external surface of the embryophore, which is rare in the Proteocephalidea. Similar structures were already observed in Proteocephalus azevedoi de Chambrier, Vaucher et Renaud, 1992 and in Nomimoscolex touzeti de Chambrier et Vaucher, 1992 (de Chambrier and Vaucher 1992, de Chambrier et al. 1992). In Pseudocrepidobothrium eirasi (Rego et de Chambrier, 1995), the eggs possess polar swellings, but this is likely due to the presence of an internal polar structure of different diameters (Rego and de Chambrier 1995). We also observed similar polar projections in Brooksiella praeputialis (Rego, Santos et Silva, 1974) (de Chambrier et al. 2004) and in Rudolphiella spp. (Gil de Pertierra and de Chambrier 2000). However, the embryophore layer of those species is distinct, presenting an elongated polar wall. Furthermore, the outer envelope of these species possesses elongated projections (Gil de Pertierra and de Chambrier 2000).

Proteocephalidean cestodes are not common parasites of lizards (Sauria: Lacertilia). They are represented by 17 currently recognized species (see Table 2) and belong to the following genera of two subfamilies: Ophiotaenia La Rue, 1911; Tejidotaenia Freze, 1965 (Proteocephalinae); Acanthotaenia von Linstow, 1903; Kapsulotaenia Freze, 1965; and Rostellotaenia Freze, 1963 (Acanthotaeniinae) (Freze 1965, Schmidt 1986). Both species described above represent the first records of proteocephalideans in gekkonid and polychrotid lizards, respectively. Previously, only Harwood (1932) reported an immature specimen of Proteocephalus sp. from Anolis carolinensis from Texas, North America.

Acknowledgements. The authors are indebted to Jean-Marc Touzet (Lyon), who collected the material in Ecuador, and Tomáš Scholz and Jean Mariaux for fruitful suggestions. We thank Fernando Escobar S., Director Nacional Forestal, and Fausto Sarmiento, Director Museo Ecuatoriano de Ciencias Naturales (both in Quito) for the authorisations of the host collection. We are grateful to André Piuz for the SEM photography, Florence Marteau and Gilles Roth (all Geneva) for finalising the drawings. This project was supported in part by the National Sciences Foundation PBI award Nos. 0818696 and 0818823. Export permit Ecuador No. 093, 21.04.1989, CITES permit Ecuador No. 018, 27.04.1989. 


\section{REFERENCES}

AMMANN M., DE CHAMBRIER A. 2008: Ophiotaenia gilberti sp. n. (Eucestoda: Proteocephalidea), a parasite of Thamnodynastes pallidus (Serpentes: Colubridae) from Paraguay. Rev. Suisse Zool. 115 (In press.)

BROOKS D.R. 1978: Systematic status of the proteocephalid cestodes of North American reptiles and amphibians. Proc. Helminthol. Soc. Wash. 45: 1-28.

CAÑEDA-GuZMÁN I.C., DE CHAMBRIER A., SCHOlZ T. 2001: Thaumasioscolex didelphidis n. gen. and n. sp. (Eucestoda: Proteocephalidae) from the black-eared opossum Didelphis marsupialis from Mexico, the first proteocephalidean tapeworm from a mammal. J. Parasitol. 87: 639-647.

DE CHAMBRIER A. 1987: Vaucheriella bicheti n. gen., n. sp. (Cestoda: Monticelliidae, Zygobothriinae) parasite de Tropidophis cf taczanowskyi (Steindachner, 1880) (Serpentes: Tropidophidae) des Andes équatoriennes. Rev. Suisse Zool 94: 829-840.

DE CHAMBRIER A. 1990: Redescription de Proteocephalus paraguayensis (Rudin, 1917) (Cestoda: Proteocephalidae) parasite de Hydrodynastes gigas (Dum., Bibr. \& Dum., 1854) du Paraguay. Syst. Parasitol. 16: 85-97.

DE CHAMBRIER A. 2001: A new tapeworm from the Amazon, Amazotaenia yvettae n. gen., n. sp., (Eucestoda: Proteocephalidea) from the siluriform fishes Brachyplatystoma filamentosum and B. vaillanti (Pimelodidae). Rev. Suisse Zool. 108: 303-316.

DE Chambrier A., D’Alessio M.L., DE Azevedo CorReA F.M. 1991: Redescription de Proteocephalus jarara (Fuhrmann, 1927) (Cestoda: Proteocephalidae) parasite de Bothrops alternatus (Viperidae) au Brésil. Rev. Suisse Zool. 98: 15-32.

DE CHAmbrier A., PAUlino R.C. 1997: Proteocephalus joanae sp. n., a parasite of Xenodon neuwiedi (Serpentes: Colubridae) from South America. Folia Parasitol. 44: 289-296.

DE Chambrier A., Rego A.A., Gil DE Pertierra A.A. 2005: Redescription of two cestodes (Eucestoda: Proteocephalidea), parasites of Phractocephalus hemioliopterus (Siluriformes) from the Amazon and erection of Scholzia gen. $\mathrm{n}$. Rev. Suisse Zool. 112: 735-752.

DE ChAMBrier A., Rego A.A., VAuCher C. 1999: Euzetiella tetraphylliformis n. gen., n. sp., (Eucestoda: Proteocephalidae), parasite du poisson d'eau douce néotropical Paulicea luetkeni (Siluriforme, Pimelodidae). Parasite 6: 43-47.

DE Chambrier A., TAKemoto R.M., PAvanelli G.C. 2006: Nomimoscolex pertierrae n. sp. (Eucestoda: Proteocephalidea), a parasite of Pseudoplatystoma corruscans (Siluriformes: Pimelodidae) in Brazil and redescription of Nomimoscolex sudobim Woodland, 1935, a parasite of $P$. fasciatum. Syst. Parasitol. 64: 191-202.

DE CHAMBrier A., VAUCHER C. 1992: Nomimoscolex touzeti n. sp. (Cestoda), a parasite of Ceratophrys cornuta (L.): first record of a Monticelliidae in an amphibian host. Mem. Inst. Oswaldo Cruz 87: 61-67.

DE ChAmbrier A., VAuCher C., RenAud F. 1992: Etude des caractères morpho-anatomiques et des flux géniques chez quatre Proteocephalus (Cestoda: Proteocephalidae) parasites de Bothrops jararaca au Brésil et description de trois espèces nouvelles. Syst. Parasitol. 23: 141-156.

DE CHAMBrIER A., VAUCHER C. 1999: Proteocephalidae et Monticelliidae (Eucestoda: Proteocephalidea) parasites de poissons d'eau douce du Paraguay avec descriptions d'un genre nouveau et de dix espèces nouvelles. Rev. Suisse Zool. 106: $165-240$
De Chambrier A., Zehnder M.P., VAuCher C., MARIAuX J. 2004: The evolution of the Proteocephalidea (Platyhelminthes, Eucestoda) based on an enlarged molecular phylogeny, with comments on their uterine development. Syst. Parasitol. 57: $159-171$.

Dos SANTOS J.C., TAYT-SON Rolas F.J. 1973: Sobre alguns cestoides de Bothrops e de Liophis miliaris. Atas Soc. Biol. Rio de Janeiro 17: 35-40.

FREZE V.I. 1965: [Proteocephalata in Fish, Amphibians and Reptiles.] Essentials of Cestodology. Vol. V. Nauka, Moscow, 538 pp. (In Russian: English translation, Israel Program of Scientific Translation, 1969, Cat. No. 1853, v +597 pp.)

FREZE V.I., RYŠAVÝ B. 1976: Cestodes of the suborder Proteocephalata Spassky, 1957 (Cestoda: Pseudophyllidea) from Cuba and description of new species Ophiotaenia habanensis sp. n. Folia Parasitol. 23: 97-104.

FuHRMANN O. 1933: Dritte Klasse des Cladus Plathelminthes Cestoidea. Kükenthal's Handbuch der Zoologie, pp. 141-416.

Gil DE PERTIERRA A.A., DE ChAMBrier A. 2000: Rudolphiella szidati n. sp. (Proteocephalidea: Monticelliidae, Rudolphiellinae) parasite of Luciopimelodus pati (Valenciennes, 1840) (Pisces: Pimelodidae) from Argentina and new observations on Rudolphiella lobosa (Riggenbach, 1895). Rev. Suisse Zool. 107: 81-95.

HARWOOD D.P.D. 1932: The helminths parasitic in the Amphibia and Reptilia of Houston, Texas and vicinity. Proc. U.S. Natl. Mus. 81: 1-71.

JOYEUX C., BAER J.G. 1961: Classe des Cestodes. In: Masson et Cie (Eds.), Traité de Zoologie, Anatomie, Systématique, Biologie. Tome 4, Plathelminthes, Métazoiares, Acanthocephales, Némertiens. P. Grassé, Masson et Cie, Paris, pp. 347-560.

MARKOWSKI S. 1952a: The cestodes of pinnipeds in the Arctic and other regions. J. Helminthol. 26: 171-214.

MARKOWSKI S. 1952b: The cestodes of seals from the Antarctic. Bull. Brit. Mus. Nat. Hist., Zool. 1: 125-150.

MARSElla C.M.V., DE CHAMBRIER A. 2008: Ophiotaenia alessandrae sp. n. (Eucestoda: Proteocephalidea), a parasite of Hyla boans (Anura: Hylidae) from Amazonia in Ecuador. Rev. Suisse Zool. 115 (In press.)

REgo A.A. 1994: Order Proteocephalidea Mola, 1928. In: L.F. Khalil, A. Jones and R.A. Bray (Eds.), Keys to the Cestode Parasites of Vertebrates. CAB International, Wallingford, pp. 257-293.

Rego A.A., ChubB J.C., PAVAnelli G.C. 1999: Cestodes in South American freshwater teleost fishes: keys to genera and brief description of species. Rev. Brasil. Zool. 16: 299-367.

REGO A.A., IVANOV V. 2001: Pseudocrepidobothrium eirasi (Rego and Chambrier, 1995), gen. n. and comb. n (Cestoda, Proteocephalidea), parasite of South American freshwater fishes, and comparative cladistic analysis with Crepidobothrium spp. Acta Sci. 21: 363-367.

RÖSLER H. 1995: Geckos der Welt. Urania-Verlag, Leipzig, Jena, Berlin, $256 \mathrm{pp}$

SCHMIDT G.D. 1986: CRC Handbook of Tapeworm Identification. CRC Press, Boca Raton, Florida, 675 pp.

SHOOP W.L., CORKUM K.C. 1982: Proteocephalus micruricola sp. n. (Cestoda: Proteocephalidea) from Micrurus diastema affinis in Oaxaca, Mexico. Proc. Helminthol. Soc. Wash. 49: 62-64.

WARDLE R.A., MC LEOD, J.A. 1952: The Zoology of Tapeworms. University of Minnesota Press, Minneapolis, 780 pp. 